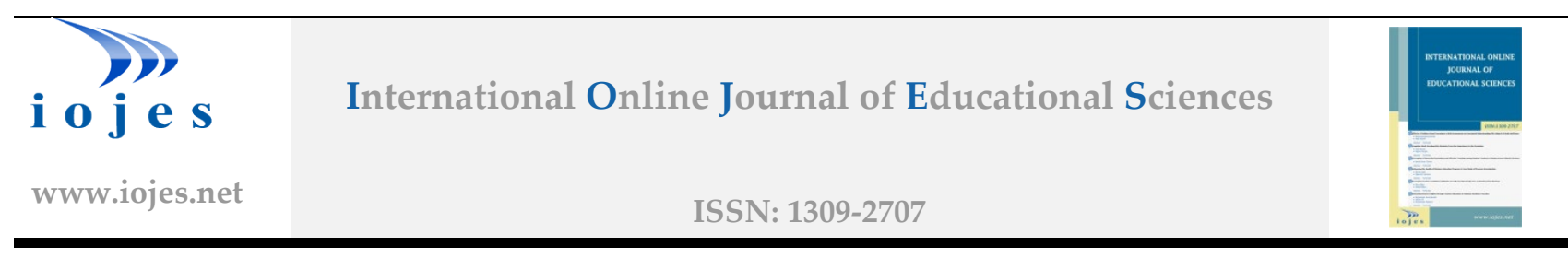

\title{
Effect of the Argumentation-Supported PBL on the Determination of Pre- Service Science Teachers' Misconceptions about the Particulate, Space, and Motion Nature of Matter
}

\section{Research Article}

\author{
Murat OKUR ${ }^{1}$, Hatice GUNGOR SEYHAN² \\ ${ }^{1}$ Sivas Cumhuriyet University, Faculty of Education, Department of Basic Education, Sivas, Turkey, ORCID: 0000-0003-2502-2276 \\ ${ }^{2}$ Sivas Cumhuriyet University, Faculty of Education, Department of Chemistry Education, Sivas, Turkey, ORCID: 0000-0001-5116-7845
}

To cite this article: Okur, M., \& Gungor Seyhan, H. (2021). Effect of the argumentation-supported PBL on the determination of pre-service science teachers' misconceptions about the particulate, space, and motion nature of matter, International Online Journal of Educational Sciences, 13(4), 1069-1088.

\begin{tabular}{|c|c|}
\hline ARTICLE INFO & ABSTRACT \\
\hline Article History: & $\begin{array}{l}\text { Within the scope of the study, the effect of the argumentation-supported problem based learning } \\
\text { method on the detection of the misconceptions of the students studying in the Department of }\end{array}$ \\
\hline Received: 18.12 .2020 & $\begin{array}{l}\text { Science Education about "Particulate, Space and Motion Nature of Matter" was examined. Based } \\
\text { on this main purpose action research in practice-based was applied in the study, one of the } \\
\text { qualitative research methods. The study group of the research consists of } 22 \text { pre-service science }\end{array}$ \\
\hline $\begin{array}{l}\text { Available } \\
\text { online:25.08.2021 }\end{array}$ & $\begin{array}{l}\text { teachers. It was observed that pre-service science teachers structured non-scientific claims, could } \\
\text { not provide sufficient grounds, and could not use their rebuttal skills adequately before the } \\
\text { implications. After the implications, it was observed that the pre-service science teachers had } \\
\text { the targeted arguments and were able to write grounds and rebuttal in the categories of } \\
\text { completely/partially correct to their arguments. }\end{array}$ \\
\hline
\end{tabular}

(C) 2021 IOJES. All rights reserved

Keywords:

Argumentation-supported implications, misconception, particulate, space and motion nature of matter, pre-service science teacher, problem based learning

\section{Introduction}

In order to raise individuals with 21st century skills, which include learning and innovation skills, life and professional skills, and knowledge, media and technology skills, it is very important to integrate these skills into education programs and use them in educational environments (Karamustafaoğlu, 2018). Studies

\footnotetext{
${ }^{1}$ Corresponding author's address: Sivas Cumhuriyet University, Faculty of Education, Department of Basic Education, Sivas, Turkey 
carried out by adding these skills to learning environments, especially within the scope of science courses, have been examined and all students support their claims with data and grounds; thus, the presence of argumentation-supported learning, which is one of the alternative approaches that encourage them to get into scientific discussion process, to think critically, to make reasoning, to make scientific decisions using scientific thinking skills draws attention (Aydoğdu, 2017; Balcı, 2015; Çekbaş, 2017; Demirel, 2017; Kalemkuş, 2018; Karakaş, 2018; Şahin, 2016; Şengül, 2018). In recent years, Ministry of National Education (MoNE) (2018) has been making improvements in science curricula that will provide learning environments in which students can easily express their opinions, support their opinions on many grounds, and rebuttal the claims of their classmates and thus develop opposite claims.

The concept of argument first came into the literature by Toulmin in 1958. Argumentation is an important part of science education, which includes group or individual thinking and writing activities (Driver, Newton \& Osborne, 2000; Osborne, Erduran \& Simon, 2004), supported and evaluated by scientific claims (Erduran \& Jimenez-Aleixandre, 2008), applied or theoretical evidence. When the literature is examined for the studies that examine the effectiveness of the argumentation-supported learning, there are also studies that result in negative feedback from the method in contrast to the positive feedback from the students. In some studies, it was observed that learners did not develop an argument skill at the expected level or they were not very active during the process (Demirel, 2015; Namdar \& Demir, 2016; Özdemir, 2015). Kuhn (2010) states that the reason why students do not show the expected level of behaviour and/or skills in science classrooms where they use argumentation- supported learning is that especially learners have difficulties in managing and structuring the relationship between argument elements such as data and argument. In the argumentation implications carried out in classrooms, it was observed that students often made similar mistakes while constructing their claims and teachers should be aware of these errors and take precautions against them in order to obtain the expected results from the implications (Driver, Newton \& Osborne, 2000). In science classes, it is necessary to prevent the difficulties students experience at these stages and to benefit from appropriate teaching strategies to improve these skills. In this context, it is stated that using a wide variety of strategies in learning environments where argumentation-supported learning is handled can help to overcome these problems. These are; table of expressions, concept maps made up of student ideas, experiment report, competing theories - theories competing with cartoons, theories competing with a story, theories competing with opinions and proofs, structure an argument, predict-observe-explain (POE) and experiment design (Osborne, Erduran \& Simon, 2004).

One of the other learning environments that enables students to consider course subjects as a problem associated with daily life events as in the argumentation-supported learning, and that enables the student who encounters the problem to try to reach a result by using his/her own knowledge in solving that problem, conducting research, discussing the data they have with their group friends is problem-based learning (PBL) (Ali, Hukamdad, Akhter \& Khan, 2010; Duch, Groh \& Allen, 2001; Torp \& Sage, 2002; Tosun, Tatar, Şenocak \& Sözbilir, 2015). The applicability of problem-based learning to science education has been researched by many researchers and it has been concluded that it is a very suitable approach for the student model of science education, and it positively affects variables such as success, critical thinking, self-efficacy, gaining researcher identity and positive attitude development (Akpınar \& Engin, 2005; Alper \& Deryakulu, 2008; Birgegard \& Lindquist, 1998; Cerezo, 2004; Özeken \& Yıldırım, 2011; Şenocak \& Taşkesenligil, 2005). In addition to studies showing that problem-based learning increases the academic achievement of students, there are also studies showing that it has no effect on academic achievement. It is thought that they will have more conscious and rich learning when problem-based learning is applied together with other learning strategies (Kılınç, 2007). While it is tried to gain high-level thinking skills; lack of knowledge occurs and focusing on problems that cause students to think only a limited subject content are some of the criticisms in problem-based learning (Banta, Black \&Kline, 2000). In many studies, incomplete knowledge acquisition of problem-based learning 
has been mentioned as a disadvantage (Dochy, Segers, Bossche \& Gijbels, 2003; Tatar, Oktay \& Tüysüz, 2009; Tosun et al., 2015). There are many studies in the educational literature on the applicability of an approach, method and technique to the education of a field. However, it has been observed that the number of researches on hybrid methods such as argumentation-supported PBL on factors (such as attitude, motivation, selfefficacy) affecting student achievement is low. As an example of these hybrid methods; problem-based learning with argumentation (Mcghee, 2015; Eyceyurt Türk, 2017); computer-aided instruction (Belland, Glazewski \& Richardson, 2011), and concept maps (Hsu, 2004; Johnstone \& Otis, 2006) are limited to those listed here. Argumentation and problem-based learning have been the subject of studies investigating the extent to which one affects the other instead of being used together (Belland, Glazewski \& Richardson, 2011; Cassel, 2002; Mcghee, 2015). Many researchers emphasize that using argumentation-supported implications in "discussion" processes in the problem-based learning to close the deficit knowledge learning gap of the problem-based learning (Kelly \& Finlayson, 2009; Nussbaum \& Edwards, 2011).

It is very important for science teaching to create curricula and course contents (theoretical and applied) for effective university level (Physics, Chemistry and Biology disciplines), to increase the academic success of pre-service science teachers, to make science concepts meaningful and to be able to be interpreted with daily life. In the scope of the study, it was aimed to determine the contribution of argumentation-supported PBL to the conceptual learning of pre-service science teachers on the subject of "particulate, space and motion nature of matter" and to examine the effectiveness of the method in determining the current misconceptions of preservice science teachers.

\section{Method}

In this study, action research in practice-based, which is one of the qualitative research methods, which aims to determine possible problems that arise in practice, the possible factors that cause these problems and possible ways of intervention, was used (Sagor, 2000).

\section{Study Group}

The study group of the research consists of 22 pre-service science teachers (19-20 years old) studying in the spring semester of the 2018-2019 academic year. The groups consist of 3-4 people. The study group of the study was determined according to the purposeful sampling type, one of the non-random sampling techniques (Creswell, 2012).

\section{Data Collection Tools}

The data collection tools of the research consist of worksheets filled by pre-service science teachers during the implications. These worksheets include activity papers that contain a problem situation for each subject and instructions that allow the argumentation process to be followed. The content validity of the data collection tool was provided by the control of two educators (science educators and chemistry educators). The reliability was provided with a 95\% consistency between the same researchers' coding and categorizing the data.

\section{Data Analysis}

In the analysis of the worksheets distributed to pre-service science teachers for argumentationsupported PBL, studies aimed at determining students' understanding and misunderstanding about many basic science concepts in the literature were examined (Abraham, Grzybowski, Renner, \& Marek, 1992; Ayvac1 \& Durmuş, 2016; Ayas, Yaman \& Kala, 2010; Balaydın \& Altınok, 2018; Birinci-Konur \& Ayas, 2010; Meşeci, Tekin \& Karamustafoğlu, 2013). The pre-service science teachers' predictions and their claims; the grounds for backing their claims; observations and data obtained during the experimental application process; in order to evaluate the scientific explanations and the level of their rebuttal, if any, the categories determined in the 
literature were used. The categories given in Table 1 were used in the analysis of the worksheets completed by the pre-service science teachers in cooperation with their group mates. While creating the categories, the answers in all categories for the misconceptions of pre-service science teachers regarding the levels of "making claim", " being able to write grounds (fact, evidence)", "collecting data", "being able to make explanation (warrant, backing, qualifier)" and "being able to rebuttal" were examined and analyzed.

Table1. Categories used for scientific claims in the analysis of worksheets

\begin{tabular}{lccc}
\hline $\begin{array}{l}\text { Categories of } \\
\text { Arguments }\end{array}$ & \multicolumn{1}{c}{$\begin{array}{c}\text { Codes used in the analysis of pre-service science teachers' responds } \\
\text { Making claim }\end{array}$} & Wrong Claim & No Claim \\
\hline $\begin{array}{l}\text { Being able to write } \\
\text { grounds (fact, } \\
\text { evidence) }\end{array}$ & $\begin{array}{c}\text { Correct Grounds } \\
\text { mpletely and Partially Correct) }\end{array}$ & Wrong Grounds & No Grounds \\
\hline $\begin{array}{l}\text { Collecting data } \\
\begin{array}{l}\text { Being able to make } \\
\text { explanation (warrant, } \\
\text { backing, qualifier) }\end{array}\end{array}$ & $\begin{array}{c}\text { Correct Data } \\
\text { mpletely and Partially Correct) }\end{array}$ & Wrong Data & No Data \\
\hline $\begin{array}{l}\text { Being able to rebuttal } \\
\text { mpletely and Partially Correct) }\end{array}$ & Wrong Explanation & No Explanation \\
\hline
\end{tabular}

\section{Implication Process}

In the study, argumentation-supported PBL implications were carried out for pre-service science teachers' conceptual learning about "particulate, space and motion natures of matter". The implications, including the argument structuring preparation activities of the pre-service science teachers, lasted for 3 weeks in total. The two-week flow chart of the implications is shown in Figure 1.

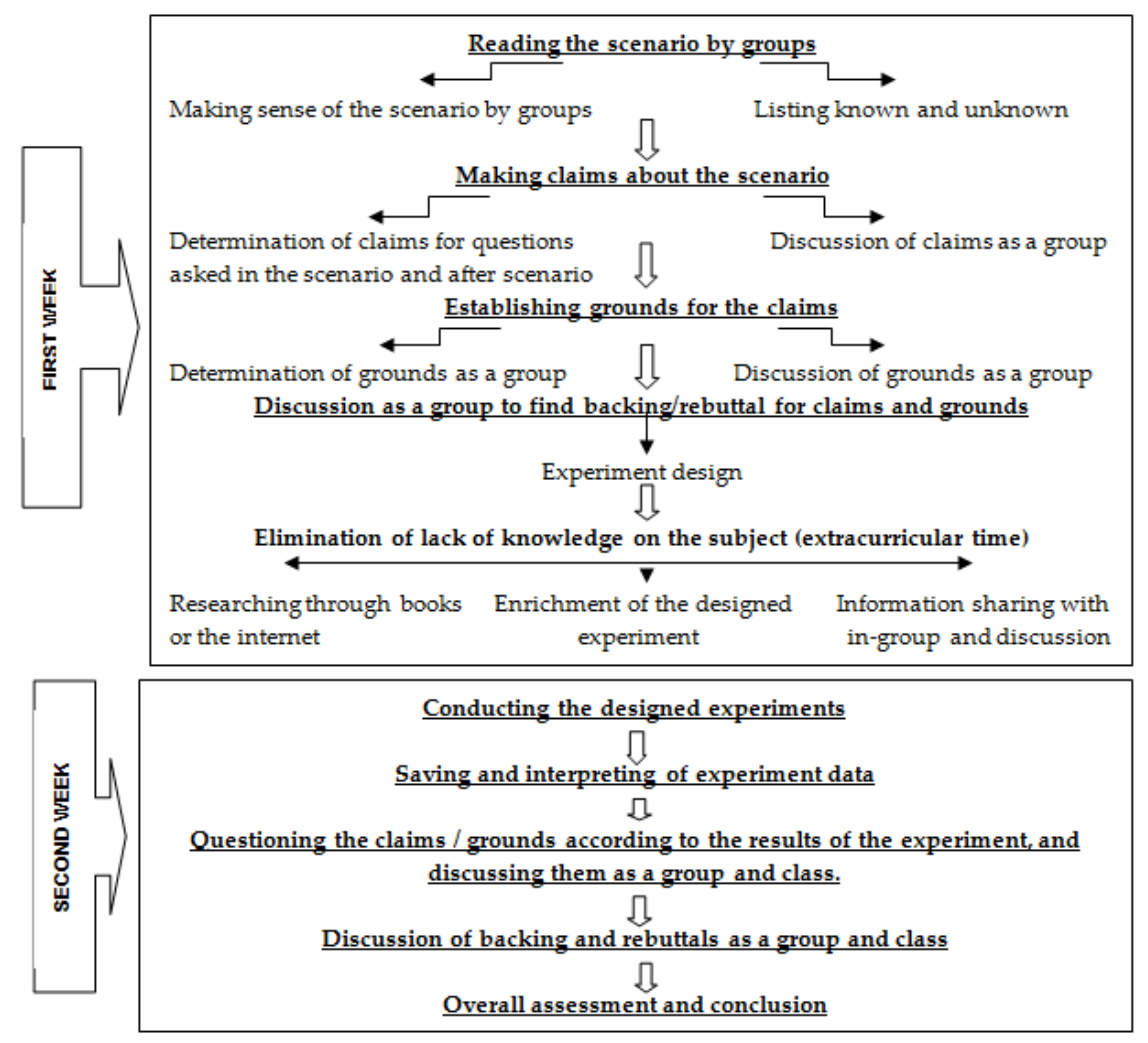

Figure 1. Argumentation-supported PBL lesson flow chart 
The pilot implications of the research were carried out with the pre-service science teachers who took the general chemistry lab-I and II course in the previous academic year (2017-2018 academic years). The pilot implications were carried out in order to detect negative situations that may arise before the main implications and to take measures. It was observed that some problems were experienced during the pilot implications, that the pre-service science teachers had difficulties especially in understanding the arguments (claim, grounds (fact, evidence, data), warrant, backing, qualifier and rebuttal) and they also had difficulties in group discussions, and this situation decreased with the increasing number of activities. The worksheets and the contents of the activities were organized as a result of the consultations made with two different educators, taking into account expert opinions, and passed on to the main implications.

Before starting the main implications for argumentation-supported PBL, preliminary studies were carried out with the pre-service science teachers to activate their argument skills in order to prepare for the implications. Preliminary studies conducted with pre-service science teachers consist of activities, which includes studies of "being able to write a claim/grounds and then design an experiment", and POE activity, where the pre-service science teacher' "predict-observe and explain" skills are examined. These pre-study activities started with a problem situation in which pre-service science teachers would use their prior knowledge and predictions. Afterwards, they were allowed to design and carry out an experimental activity that they would observe, and consequently, their ability to record their observations was activated in this process. In the last stages of the pre-study activities, an environment was provided in which they compared their predictions and the results they obtained based on the data they obtained during their observations. During all these pre-activity stages, pre-service science teachers worked as a group. During the pre-study, the conceptual learning of the relevant subject targeted within the scope of the study was started with the preservice science teachers who had information about the stages of an argument structuring process. The argumentation-supported PBL for the relevant chemistry subject given to pre-service science teachers were carried out for 2 weeks. They made pre-studies to design an experiment by forming their arguments for the problem situation given in the first week. In the second week, they had the opportunity to test the claims they had created in the previous lesson by carrying out the experiments they planned in the laboratory, and they explained them by comparing them after the experiments.

\section{Findings and Interpretation}

During the argumentation-supported PBL about the particulate, space and motion natures of the matter, the pre-service science teachers were asked to fill in the worksheets distributed to them with their group friends. The worksheets start with a problem situation that requires an experimental process. The claims given by the pre-service science teachers in the worksheets were analyzed by content analysis and the findings obtained are presented in Table 2. The claims of the pre-service science teachers were criticized based on the following scientific claims (Atasoy, 2018):

(- All matters in solid, liquid and gas state under any pressure and temperature conditions consist of particles. The structures, sizes and chemical formulas of the particles in these three states are the same for any matter. The difference is the kinetic energies of the particles, the spaces between the particles, and the way the particles come together.

(-) The solid, liquid and gas state of the matters is mentioned, but the particles that make up the matters do not have the state. There is no such thing as solid particle, fast particle or gas particle. The particles in all three of the matters are the same particles.

๑ The mass, size and chemical composition of the particles in all three states of a matter are the same. If this were not so, the mass of some of a matter in solid, liquid and gas states would have been different. 
(-) The movement of particles of matter is not the same for the three states of matter. The solid particles of the materials also have only vibrational movements and therefore the inter particles spaces are constant. In other words, the places of the particles are fixed. In addition to the vibrational movement of the liquid and gas particles of the matter, there are translational movements resulting from the rotation and displacement caused by the collisions of the particles. However, these movements in liquids are slower than gases. As is known, if there is movement in a system, that system has a kinetic energy.

(2) The property of a matter is determined by the properties of its particles and the way the particles come together. In other words, the particles of any matter do not have the properties of the macroscopic structure of that matter.

In order to determine the claim levels of the pre-service science teachers about the specified chemistry subject, the problem situation given in Figure 2 was presented by the researchers and then they were asked to write their claims and grounds for the main problem sentence.

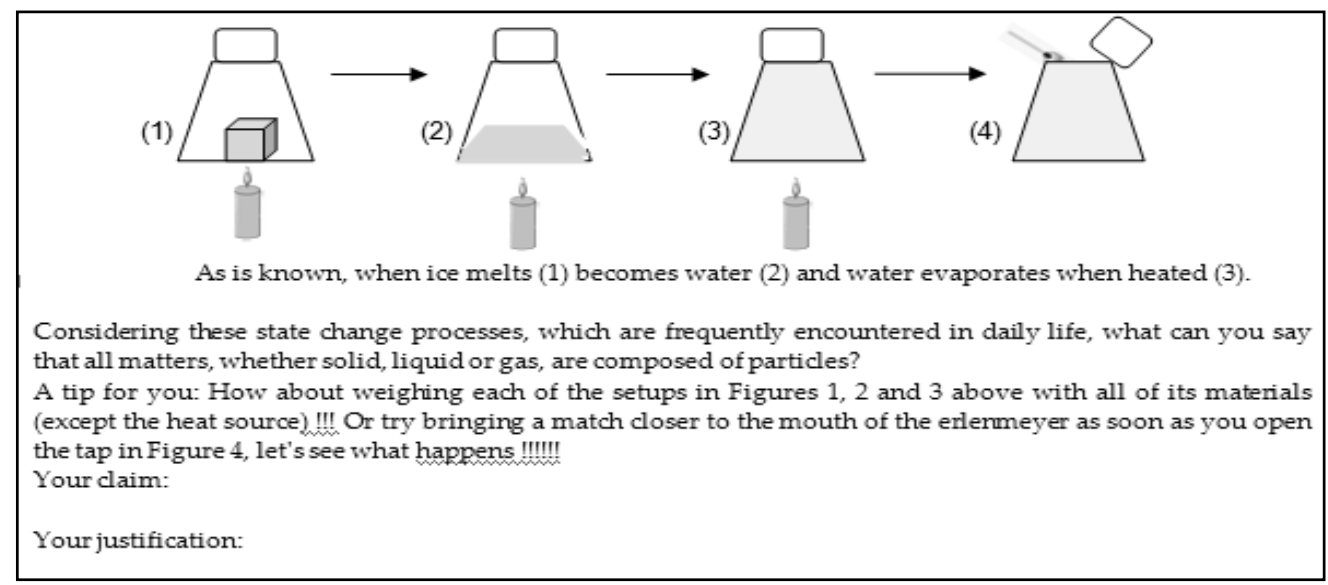

Figure 2. Problem situation regarding the particulate nature of matter

Following the claims and grounds put forward by the pre-service science teachers with their group mates, the following questions were directed to all group members by the researchers:

- Think of an iron bar. The iron bar is heated and beaten and turned into a plate. How did an iron bar become a plate? In this case, what could have changed in iron so that it could become a plate?

- A tip for you: Do you think there is a correlation between the heating of an iron bar to become a plate and further thinning by being beaten, and children playing on the beach smoothing small piles of sand with their hands?

With the answers given by the group members to all the questions above, the researchers obtained clues about pre-service science teachers' preliminary knowledge about the "particulate nature of matter". Afterwards, pre-service science teachers were asked to perform their experiments according to the experimental setup given in Figure 2. They were asked to write all their observations during the experiment process in the relevant places in the worksheets distributed to them. This stage is the process in which the students are questioned whether their pre-experimental predictions (their claims to researchers and other classmates) are compatible with their observations during the process and the data they have obtained. The last explanations made by the group members about the compatibility of the data obtained from their observations with the claims before the experimental process gave the researchers clues about the change in the argument levels of the pre-service science teachers, and the frequencies and percentages of all findings obtained are summarized in Table 2. 
Table 2. Categories and codes of argument levels of pre-service science teachers about the particulate nature of matter

\begin{tabular}{|c|c|c|c|c|c|c|c|c|}
\hline Categories of & Co & sed in the ar & lys & re-servic & ence & ers' respon & & \\
\hline & & Corre & $\mathrm{Cl}_{c}$ & & & & & \\
\hline Mlling laim & $\mathrm{Co}$ & tely Correct & $\mathrm{Pa}$ & Correct & & (5 tami & & (1) \\
\hline & $\mathrm{f}$ & $\%$ & $\mathrm{f}$ & $\%$ & $\mathrm{f}$ & $\%$ & $\mathrm{f}$ & $\%$ \\
\hline & 4 & 18 & 6 & 27 & 12 & 55 & - & - \\
\hline & & Correc & Gro & & & & & \\
\hline orounds (fact & $\mathrm{Co}$ & tely Correct & $\mathrm{Pa}$ & Correct & & Givuitus & & s tertus \\
\hline evidence) & $\mathrm{f}$ & $\%$ & $\mathrm{f}$ & $\%$ & $\mathrm{f}$ & $\%$ & $\mathrm{f}$ & $\%$ \\
\hline & 4 & 18 & - & - & 12 & 55 & 6 & 27 \\
\hline & & Corr & ct $\mathrm{D}$ & & $\mathrm{Wr}$ & ata & No & \\
\hline Collecting data & $\mathrm{f}$ & & $\%$ & & $\mathrm{f}$ & $\%$ & $\mathrm{f}$ & $\%$ \\
\hline & 22 & & 100 & & - & - & - & - \\
\hline Being able to make & & Correct & xpla & & $W \boldsymbol{r}_{\mathrm{r}}$ & volonotion & No & nation \\
\hline explanation & $\mathrm{Co}$ & tely Correct & $\mathrm{Pa}$ & Correct & pvi & Xlantiont & 100 & mation \\
\hline (warrant, backing, & $\mathrm{f}$ & $\%$ & $\mathrm{f}$ & $\%$ & $\mathrm{f}$ & $\%$ & $\mathrm{f}$ & $\%$ \\
\hline qualifier) & 8 & 36 & 14 & 64 & - & - & - & - \\
\hline & & Correc & Reb & & $W r_{r}$ & obuttal & No & \\
\hline Being able to & $\mathrm{Co}$ & ely Correct & Par & Correct & 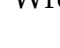 & 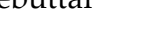 & 100 & \\
\hline rebuttal & $\mathrm{f}$ & $\%$ & $\mathrm{f}$ & $\%$ & $\mathrm{f}$ & $\%$ & $\mathrm{f}$ & $\%$ \\
\hline & 8 & 36 & 4 & 18 & - & - & 10 & 46 \\
\hline
\end{tabular}

The pre-service science teachers were asked to write their claims and grounds about the particulate nature of matter, depending on the comparison of the total masses of the matters before and after the state changes for "the process of heating an ice cube placed in a closed conical flask to water and then to water vapour by continuing to heat it". Only one group (3rd group) of the pre-service science teachers gave answers in the category of making correct claims and providing correct grounds (18\%): "The particles of solid matter are found very close to each other. In the liquid state there is some distance, while in the gas state they are quite far apart. We can compare the solid state to the fact that people get closer to each other when they get very cold. But as we get warmer, we keep distance from people, and when the environment is very hot, we move away from each other. When the air is very close to each other, we look like a single piece, but as the distance between us and people grows, we all start to look like a single piece, just like this, there are actually a lot of particles in the ice cube, in water and in water vapour". $27 \%$ of the pre-service science teachers made partially correct claims, the pre-service science teachers representing this group are the students who could not provide grounds and as an example to the sentences: "The solid state materials turn into water when they get heat, if they continue to get heat, they turn into gas. We know that metals such as iron can turn into wires and plates, when they are heated they become plates more easily". $55 \%$ of the pre-service science teachers submitted wrong claims and wrong grounds to the given problem situation: "As matter changes state, its particles will also change state. Therefore, the liquid and gas nature of the matter take the shape of the flask in which it is placed. Thus, the solid state (ice cube) occupied a very small part of the flask, while the gas state covered the entire flask"; "When a bar made of iron is hit with a hammer by heating, the iron atoms will also be crushed, so the particles that make up the iron by being crushed flatten". All of the pre-service science teachers (100\%) were able to collect the data correctly in the experimental procedure process requested by the researchers. After comparing the compatibility of the pre-service science teachers' claims and grounds after the process requiring experimental processing with the data they obtained, there were two groups of students (36\%) who were able to present completely correct explanation and correct rebuttal: "When we control the weighing results during the whole process, we have proved that the process is both physical change and there is no material loss, as the results are the 
same"; "We did not open the plug of the Erlenmeyer flask until the end of the process, and we did not lose any matter because there was no product coming out, so during the process change, the particles that make up the matter only changed in the distance between them"; "Then we can say that all matters, such as water in a liquid state or a matter with an ice in a solid state, were created by an array of particles with varying distance ratios between them. We did not expect to observe anything when the match got closer, there would be water vapour coming out of the conch, because this substance is the gaseous state of the matter whose liquid state is water. Water vapour is not a matter that catches fire even more". The remaining $64 \%$ of the pre-service science teachers made explanations at the level of partially correct explanation, but $18 \%$ of this group of students were able to partially correct rebuttal and the remaining students could not responds at the level of rebuttal.

When all the feedbacks of the pre-service science teachers about the particulate nature of matter were examined, it was observed that the multi-spaced and motion model of matter was tried to be explained rather than the particulate model. In the experimental implication process, the pre-service science teachers were asked questions by the researchers: "Your weighing results are equal as shown in all three figures, what grounds you give for this? (- It shows that there is no matter loss), well, the solid and liquid state of the substance can be seen, but what could be the reason why water vapour, which is the gas state, cannot be seen clearly? (-With the evaporation of the water, the gas particles (molecules) spread throughout the flask in which they are placed) (36\%)".

None of the pre-service science teachers could give satisfactory responds to the question of how the iron bar can easily turn into a plate when heated. However, the purpose of heating the iron rod is to increase the vibrations of the particles forming the iron thanks to the heat and thus to make them move away from each other, that is to make them more forgeable. By forging the iron plate, the iron atoms whose affinity force between them decreases by sliding over each other and dispersing them. This situation can be compared to the manual smoothing of sand grains in sand heaps. When iron sheet is forged into shape, the atoms neither flatten nor expand with the effect of temperature.

In order to reveal the pre-knowledge of the pre-service science teachers about the "spaced nature of matter", the group members were presented with the problem situation given in Figure 3, and then they were asked to write their claims and grounds for the main problem sentence.

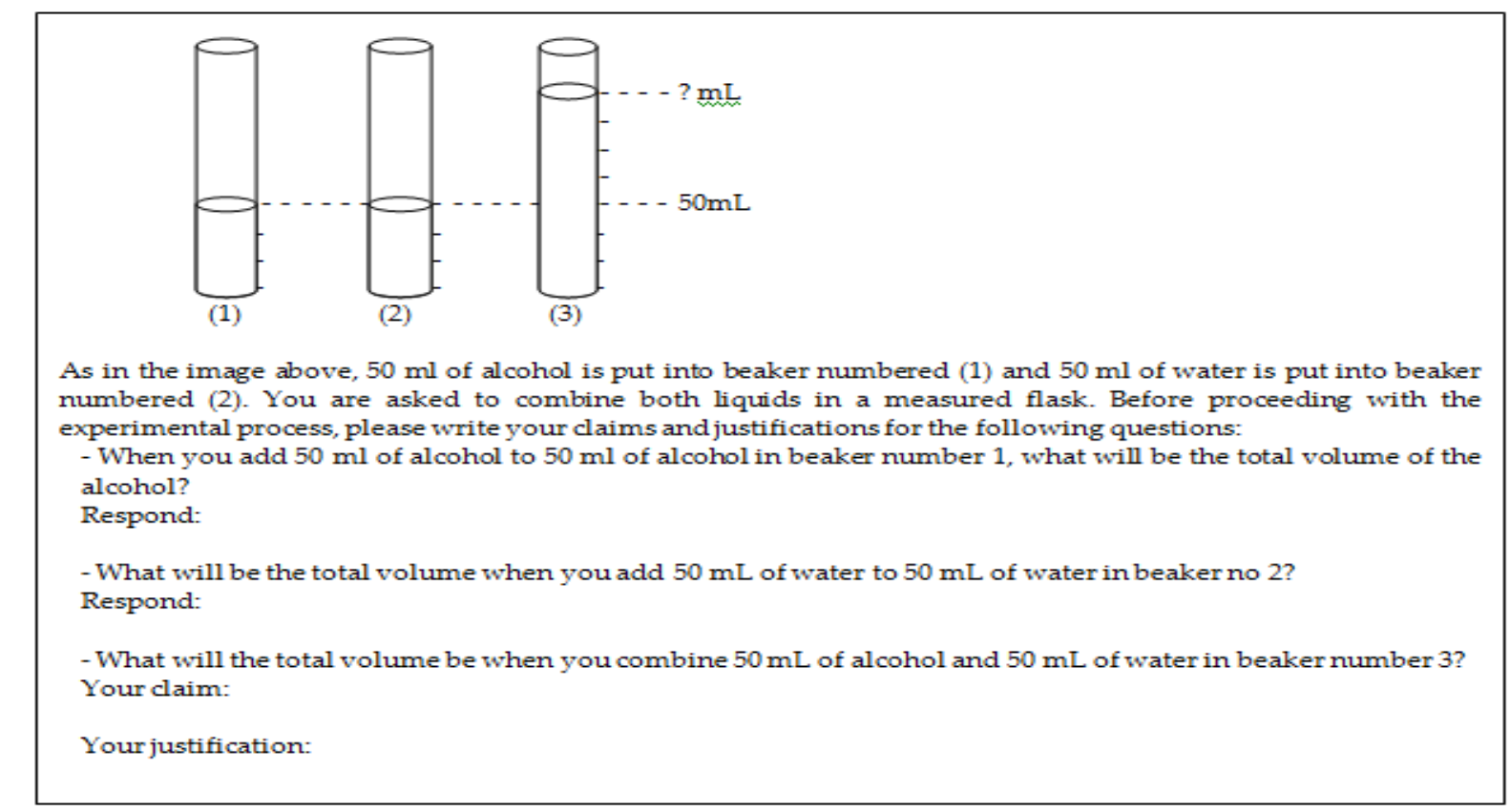

Figure 3. Problem situation regarding the space nature of matter 
Following the claims and grounds of the pre-service science teachers and their group mates for the problem situation given in Figure 3, the following questions were directed to all group members by the researchers:

-Before proceeding to the above experimental process, put $50 \mathrm{~mL}$ of chickpeas in a graduated container as above. Put $50 \mathrm{~mL}$ of sand in another grade container. Then add chickpeas in a bowl filled with sand. What did you observe? Please write.

-Have you ever thought about what might happen if a drop of red colour solution (such as ink) is dropped on a surface made of solid matter such as wood, glass or tile? Please write down your data regarding your observations with your grounds.

With the responds given by the group members to all the above questions, the researchers obtained clues about the pre-knowledge of the pre-service science teachers about "the space nature of matter" and all the findings obtained are shown in Table 3. Afterwards, the pre-service science teachers were asked to perform their experiments according to the experimental setup given in Figure 3. They were asked to write all their observations during the experimental process in the relevant places in the worksheets distributed to them. The last explanations made by the group members about the compatibility of the data obtained from their observations with their claims and grounds before the experimental process and their rebuttal, if any, gave clues to the researchers about the changes in the pre-service science teachers' argument levels, and all the findings obtained are summarized in Table 3.

Table 3. Categories and codes of argument levels of pre-service science teachers about the space nature of matter

\begin{tabular}{|c|c|c|c|c|c|c|c|c|}
\hline $\begin{array}{l}\text { Categories of } \\
\text { Argument }\end{array}$ & Cod & in the ar & lysis & rvic & ence & s' respon & & \\
\hline & & Corre & $\mathrm{Cla}$ & & & & & \\
\hline Making claim & $\mathrm{Col}$ & Correct & Par & rect & 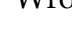 & & & \\
\hline & $\mathrm{f}$ & $\%$ & $\mathrm{f}$ & $\%$ & $\mathrm{f}$ & $\%$ & $\mathbf{1}$ & $\%$ \\
\hline & - & - & 10 & 45 & 12 & 55 & - & - \\
\hline & & Correct & Grou & & & & & \\
\hline orounds (fact & Cor & Correct & Par & rect & & & & \\
\hline evidence) & $\mathrm{f}$ & $\%$ & $\mathrm{f}$ & $\%$ & $\mathrm{f}$ & $\%$ & $\mathrm{f}$ & $\%$ \\
\hline & - & - & 7 & 32 & 8 & 36 & 7 & 32 \\
\hline & Cor & & & & Wro & & & \\
\hline Collecting data & $\mathrm{f}$ & & $\%$ & & $\mathrm{f}$ & $\%$ & $\mathrm{f}$ & $\%$ \\
\hline & 22 & & 100 & & - & - & - & - \\
\hline Being able to make & & Correct $\mathrm{E}$ & plan & & W Imo & lanation & & \\
\hline explanation & Cor & Correct & Par & ect & WVro & lanation & & \\
\hline (warrant, backing, & $\mathrm{f}$ & $\%$ & $\mathrm{f}$ & $\%$ & $\mathrm{f}$ & $\%$ & $\mathrm{f}$ & $\%$ \\
\hline qualifier) & 11 & 50 & 11 & 50 & - & - & - & - \\
\hline & & Correct & Rebu & & Who & 1 & & \\
\hline Being able to & Con & Correct & Part & & vvice & (t) & & \\
\hline rebuttal & $\mathrm{f}$ & $\%$ & $\mathrm{f}$ & $\%$ & $\mathrm{f}$ & $\%$ & $\mathrm{f}$ & $\%$ \\
\hline & 11 & 50 & 7 & 32 & - & - & 4 & 18 \\
\hline
\end{tabular}

For the problem situations "What will be the total volume of $50 \mathrm{~mL}$ alcohol and $50 \mathrm{~mL}$ of alcohol or when 50 $\mathrm{mL}$ of water and $50 \mathrm{~mL}$ of water are pooled in a measuring cup", the responds of the pre-service science teachers were taken, and after making observations, again "What will be the total volume of $50 \mathrm{~mL}$ of alcohol and $50 \mathrm{~mL}$ of water are pooled in a measuring cup", the claims and grounds of the pre-service science teachers asked in writing. 
$45 \%$ of the pre-service science teachers responded in the partially correct claim category: "When $50 \mathrm{~mL}$ of water is pooled with $50 \mathrm{~mL}$ of alcohol, the total volume is expected to be $100 \mathrm{~mL}$ just like two alcohol or water samples. Because alcohol and water do not react". 55\% of the pre-service science teachers made wrong claims, students in this category said, "When both liquid samples are pooled in the same amount, the total volume will be $100 \mathrm{~mL}$ just like alcohol and water samples, the total volume will be $100 \mathrm{~mL}$ ". "Like water, alcohol is a transparent but scented liquid and its volatility is very high and the total volume will be $100 \mathrm{~mL}$ ". Although $55 \%$ of the pre-service science teachers made a partially correct claim, 32\% were able to provide partially correct grounds: "Alcohol and water do not dissolve in each other. But because the two liquids are different types, it means that their particles are also different". 36\% of the pre-service science teachers were found to have misconceptions by presenting grounds in the category of wrong grounds: "Since alcohol is a very volatile liquid, its total volume will be less when pooled with water", "Alcohol and water will react, the total volume will be less". $32 \%$ of the pre-service science teachers did not provide any grounds for this problem. After the claims and grounds of the pre-service science teachers were obtained, they were asked to perform the experimental procedures (alcohol + water and chickpea + sand samples). After the experimental process, $50 \%$ of the pre-service science teachers made correct explanations and $50 \%$ of them gave partially correct explanations: "The particles of alcohol and water samples are also different. Therefore, the spaces between the particles will also be different", "We can compare the particles of alcohol to chickpea samples, and we can compare the water to the sand sample. The grains of sand will diffuse the spaces between the chickpea grains, and the total volume has decreased as the particles that make up the water will diffuse between the particles that make up the alcohol". The pre-service science teachers were also able to use their rebuttal skills after all the applications. $50 \%$ of the group students were able to refute in the completely correct category: "Colored solutions such as ink remain when dropped on the glass surface, but on surfaces such as wood, where the space between the particles is large enough to allow the particles of water to diffuse, the surface will absorb water". $32 \%$ of the pre-service science teachers refuted in the partially correct category: "Alcohol and water are both transparent liquid solutions, and when both samples are pooled, the total volume is $100 \mathrm{~mL}$, but in the sand and chickpea sample, the total volume may not always be $100 \mathrm{~mL}$ when chickpeas are pooled". $18 \%$ of the pre-service science teachers did not refute.

It was observed that pre-service science teachers used more and more advanced argument skills in their conceptual understanding about the space model of matter compared to the particle model of matter. Although the analogy of alcohol-water samples is made with the chickpea-sand model based on the combination of alcohol-alcohol and water-water samples, this model confirms the model in which the particulate nature of the matter and the space between the particles is accepted. With the chickpea-sand analogy, students are reminded that alcohol and water particles should not be considered global. When colored solutions are dropped on surfaces such as wood, the particles that make up the liquid diffused the spaces between the particles of the matter that make up the wood. However, since the particles in the solid cannot move, the particles of the liquid are trapped between the particles of the solid. The reason why colored liquids remain on surfaces such as glass and tiles is that the space between the particles in glass and tiles is not large enough for the particles of the liquid to diffuse.

The problem situation given in Figure 4 was presented to the group members in order to reveal the preknowledge of the pre-service science teachers about "motion nature of matter", and then they were asked to write their claims and grounds for the main problem statement. 
When you come home from school with a very hungry stomach, have you ever realized which food was cooked at the entrance of the apartment? Or, have you ever thought why your eyes tears when you or your mother chop onions? Or, how can the smell of naphthalene used by your grandmothers to protect your winter wool dothes come to our nose? Let's ask a more theoretical question, how can you explain the pressure of a gas compressed in a bin?

-Your claims:

-Your justifications:

Figure 4. Problem status regarding the motion nature of matter

After the claims and grounds of the pre-service science teachers and their group mates for the problem situations given in Figure 4, the researchers were asked to do the following experimental procedures to all group members:

- Very carefully pour some concentrated ammonia $\left(\mathrm{NH}_{3}\right)$ on a piece of cotton and some hydrochloric acid $(\mathrm{HCl})$ on another cotton. And, without wasting time, place both cotton balls at both ends of a long thin glass tube. What did you observe?

- Have you ever thought about what might happen after you wait for a while when you drop 1-2 drops of ink or a colored solution into a small amount of still water in a beaker?

- Or how do you explain the heating of the edge of an iron bar that we hold with our hands, one edge of which is held on fire?

With the answers given by the group members to all the questions above, the researchers obtained clues about the pre-knowledge of the pre-service science teachers about "the motion nature of matter" and all the findings obtained are shown in Table 4. The pre-service science teachers were asked to perform their experiments according to all the experimental setups for the above questions posed by the researchers. They were asked to write all their observations during the experimental process in the relevant places in the worksheets distributed to them. The last explanations made by the group members regarding the compatibility of all the data they obtained from their observations with their claims and grounds before the experimental process and their rebuttal-if any, gave clues to the researchers about the change in the argument levels of the pre-service science teachers and all the findings obtained are summarized in Table 4.

Table 4. Categories and codes of argument levels of pre-service science teachers about the motion nature of matter Categories of argument

Codes used in the analysis of pre-service science teachers' responds

\begin{tabular}{|c|c|c|c|c|c|c|c|c|}
\hline \multirow{4}{*}{ Making claim } & \multicolumn{4}{|c|}{ Correct Claim } & \multirow{2}{*}{\multicolumn{2}{|c|}{ Wrong Claim }} & \multirow{2}{*}{\multicolumn{2}{|c|}{ No Claim }} \\
\hline & \multicolumn{2}{|c|}{ Completely Correct } & \multicolumn{2}{|c|}{ Partially Correct } & & & & \\
\hline & $\mathrm{f}$ & $\%$ & $\mathrm{f}$ & $\%$ & $\mathrm{f}$ & $\%$ & $\mathrm{f}$ & $\%$ \\
\hline & 7 & 32 & 15 & 68 & - & - & - & - \\
\hline \multirow{4}{*}{$\begin{array}{l}\text { Being able to write } \\
\text { grounds (fact, } \\
\text { evidence) }\end{array}$} & \multicolumn{4}{|c|}{ Correct Grounds } & \multirow{2}{*}{\multicolumn{2}{|c|}{ Wrong Grounds }} & \multirow{2}{*}{\multicolumn{2}{|c|}{ No Grounds }} \\
\hline & \multicolumn{2}{|c|}{ Completely Correct } & \multicolumn{2}{|c|}{ Partially Correct } & & & & \\
\hline & $\mathrm{f}$ & $\%$ & $\mathrm{f}$ & $\%$ & $\mathrm{f}$ & $\%$ & $\mathrm{f}$ & $\%$ \\
\hline & 7 & 32 & 8 & 36 & - & - & 7 & 32 \\
\hline \multirow{3}{*}{ Collecting data } & \multicolumn{4}{|c|}{ Correct Data } & \multicolumn{2}{|c|}{ Wrong Data } & \multicolumn{2}{|c|}{ No Data } \\
\hline & $\mathrm{f}$ & & $\%$ & & $\mathrm{f}$ & $\%$ & $\mathrm{f}$ & $\%$ \\
\hline & 22 & & 100 & & - & - & - & - \\
\hline \multirow{3}{*}{$\begin{array}{l}\text { Being able to make } \\
\text { explanation }\end{array}$} & \multicolumn{4}{|c|}{ Correct Explanation } & \multirow{2}{*}{\multicolumn{2}{|c|}{ Wrong Explanation }} & \multirow{2}{*}{\multicolumn{2}{|c|}{ No Explanation }} \\
\hline & $\mathrm{Co}$ & ly Correct & & Correct & & & & \\
\hline & $\mathrm{f}$ & $\%$ & $\mathrm{f}$ & $\%$ & $\mathrm{f}$ & $\%$ & $\mathrm{f}$ & $\%$ \\
\hline
\end{tabular}




\begin{tabular}{|c|c|c|c|c|c|c|c|}
\hline $\begin{array}{l}\text { (warrant, backing, } \\
\text { qualifier) }\end{array}$ & 11 & 50 & 11 & 50 & - & - & - \\
\hline \multirow{4}{*}{$\begin{array}{l}\text { Being able to } \\
\text { rebuttal }\end{array}$} & \multicolumn{4}{|c|}{ Correct Rebuttal } & \multirow{2}{*}{ Wrong Rebuttal } & \multirow{2}{*}{\multicolumn{2}{|c|}{ No Rebuttal }} \\
\hline & \multicolumn{2}{|c|}{ Completely Correct } & \multicolumn{2}{|c|}{ Partially Correct } & & & \\
\hline & $\mathrm{f}$ & $\%$ & $\mathrm{f}$ & $\%$ & $\%$ & $\mathrm{f}$ & $\%$ \\
\hline & 4 & 18 & 7 & 32 & - & 11 & 50 \\
\hline
\end{tabular}

All of the pre-service science teachers were able to make correct claims about the "the motion nature of matter", but $32 \%$ of these students made claims in the completely correct category and $68 \%$ of them in the partially correct category. Group students who submit a claim in the completely correct category said: "The reason why we tear our eyes while chopping onions is the gas that comes out of the onion and makes our eyes tear", "When we spray deodorant in one corner of the room, after a short while, as someone in the other corner of the room smells it, it is also the movement of particles of gas matter in our smell when we entering the apartment". For claims in the partially correct category they said, "Naphthalene is a substance that bypasses its liquid state at room temperature and passes into the gas phase, we can smell the gases from naphthalene, which gradually passes into the gas phase". 32\% of the pre-service science teachers were able to write exactly the correct reason: "The particles of gas matter can do all vibration, translator and rotational movements, so they spread over a large surface in a short time". $36 \%$ of the students, on the other hand, realized their applications with partially correct grounds: "Gas matter move faster because the space between the particles is large". With the guidance of the researchers, the pre-service science teachers who carried out all the experimental applications, together with the data they obtained from their observations, then their scientific explanation and rebuttal skills were examined. $50 \%$ of the pre-service science teachers made explanations in the completely correct category and the remaining $50 \%$ in the partially correct category: For completely and partially correct categories: The white smoke that emerges near the $\mathrm{HCl}$ side after the cotton with $\mathrm{HCl}$ and $\mathrm{NH}_{3}$ placed at both edges of a long thin glass tube is $\mathrm{NH}_{4} \mathrm{Cl}$. In other words, it is a gas formed by the reaction of $\mathrm{HCl}$ and $\mathrm{NH}_{3}$. It is formed by the reaction of the solutions dropped on these two cotton to react. That is, the particles of these two solutions are mobile that they could react even though they were put away from each other" or " $\mathrm{NH}_{4} \mathrm{Cl}$, a white smoke, was formed by the reaction of $\mathrm{HCl}$ and $\mathrm{NH}_{3}$ in the glass tube" can be given. Within the scope of the applications, $18 \%$ of the pre-service science teachers used the correct rebuttal skills, $32 \%$ partially correct, and 50\% did not refute the subject of "The Motion Nature of Matter". As an example of the answers that the pre-service science teachers used their rebuttal skills; "When a colored solution such as ink is dropped into still water, it disperses after a while, the reason may be that the particles of the solution in liquid form are motion", "We can explain the heating of a metal whose one edge is kept on fire until the part that does not touch fire" When we tell a few of our friends to move, they will only be able to vibrate in their places, but if we said to move in a way that they touch each other a little, they will both vibrate in their places and also rotate around themselves and even partially change their place, which explains the state of taking the shape of the bin in which they are placed".

It was observed that pre-service science teachers did not have misconceptions in the implications carried out for the motion nature of matter within the scope of the argumentation-supported PBL. The movements of the particles in the matters are different for all three states of the matters. While the particles in the solid nature of the matters are only in vibrational motion, the spaces between the particles are also fixed. Liquid and gas particles have translational movements caused by rotation and substitution caused by collisions, including vibration. However, these movements in the particles in liquids are slower than those in gas.

The most striking finding after argumentation-supported PBL is that pre-service science teachers usually construct non-scientific arguments before the activity, and after the activity, they change their wrong and or incomplete/inadequate arguments, form scientific arguments and realize their misconceptions and correct them. Furthermore, it was observed that while the pre-service science teachers could not justify many of their arguments before the experiments they carried out during the activities, they were able to write 
completely or partially correct explanations and refutes for their arguments in the light of the data they obtained based on their observations during the experimental procedures they were expected to do in practice.

\section{Results and Discussion}

The reasons why chemistry is seen as a difficult discipline for students; it can be thought by both teachers and researchers that the way many chemical events occur is unfamiliar to learners and that the language used by chemistry is difficult to express these events. All these cause students to develop misconceptions about some chemical concepts (Ayas \& Demirbaş, 1997; Hewson \& Hewson, 1983; Nakhleh, 1992; Zoller, 1990; Pardo \& Partoles, 1995). Studies conducted to determine students' pre-knowledge and misconceptions show that misconceptions are not specific to a particular age group and are carried by students from all groups and levels (Bar \& Travis, 1991; Fensham, Gunstone \& White, 1995; Gonzalez, 1997; Özmen, 2005). If there are misconceptions in the students' pre-knowledge, these may not only interpret new information, but also sometimes prevent the comprehension of new information and lead to new misconceptions, which can increase the formation of undesired learning products (Andersson, 1986; Griffiths \& Preston, 1992).

Concept teaching in learning-teaching environments has an important place in revealing students' misconceptions. Misconception about a phenomenon/event or concept negatively affects the learning of other subjects. Therefore, it is important to diagnose and eliminate misconceptions in advance. In this context, educators should plan their learning-teaching environments by taking the prior knowledge of students into consideration and make arrangements to eliminate existing misconceptions beforehand. Considering from this point of view, one of the learning-teaching environments that can be used in the diagnosis and elimination of misconceptions in science education is the argumentation-supported PBL practices that we have discussed in the scope of the study. In order to increase the quality of teaching and contribute to the development of science education, it is widely accepted that pre-knowledge and advanced misconceptions about concepts in students must first be identified and then changed (Hackling \& Garnett, 1985; Taber, 1999). As a result, there are an increasing number of studies on basic concepts to determine students' level of understanding. Methods such as concept mapping, interviews, drawings, tests are used in studies on the detection of misconceptions and levels of understanding (White \& Gunstone, 1992). Although many different techniques are used to reveal students' pre-knowledge and diagnose misconceptions, concept map (Hazel \& Prosser, 1994), predictionobservation-explanation (POE) technique in argumentation based learning (Liew \& Treagust, 1994), and interviews about events and situations (Osborne \& Gilbert, 1980; Osborne \& Cosgrove, 1983; Scaife \& Abdullah, 1997), full/semi-structured student views on concepts, student drawings (Smith \& Metz, 1996), word association (Maskill \& Cachapuz, 1989), two/three/four-stage diagnostic tests (Karslı \& Çalık, 2012; Treagust \& Chandrasegaran, 2007; Tüysüz, 2009; White \& Gustone, 1992) or different combinations of related techniques are the most commonly used techniques. In recent years, it has been observed that the studies carried out in science education are aimed at determining student understanding of the basic concepts in science and to identify and eliminate the existing misconceptions: In chemistry education, it has been determined that there are studies aimed at detecting and eliminating the current misconceptions in students for almost all concepts in chemistry: chemical balance (Hackling \& Garnett, 1985; Voska \& Heikkinen, 2000; Yamtinah et al., 2019; Yıldırım, Demircioğlu, Özmen \& Ayas, 2000), acids and bases (Demircioğlu, Özmen \& Ayas, 2001; Özmen, 2003; Özmen \& Demircioğlu, 2003), solutions and solubility (Ebenezer \& Fraser, 2001; Çalık, 2003; Kalın \& Arıkıl, 2010); colligative properties (Coştu, Ayas, Açıkar \& Çalık, 2007; Çalık \& Ayas, 2008; Demircioğlu \& Vural, 2014; Özmen, 2002); electrochemistry and electrolytic conductivity (Çalık \& Ayas, 2005; Garnett \& Treagust, 1992), reaction rate (Çakmakcı, Leach \& Donnelly, 2006; Kolomuç \& Tekin, 2011), particulate nature of matter (Akman \& Özdilek, 2018; Balım \& Ormancı, 2016; Çavdar, Okumuş \& Doymuş, 2016; Kenan \& Özmen, 2011; Meşeci, Tekin \& Karamustafaoğlu, 2013; Mısır \& Laçin Şimşek, 2017). 
In this study, the misconceptions of pre-service science teachers about the particulate, space and motion nature of matter were investigated with the activities carried out within the scope of the argumentationsupported PBL was determined. This situation once again demonstrated that misconceptions on the relevant topic are ideas that are extremely resistant to change in all cultures and class levels. When the data in Tables 2, 3 and 4 are examined for the current misconceptions in pre-service science teachers, it was observed that all misconceptions were determined at "Being able to write grounds" argument level, and that implications within the argumentation-supported PBL could be effective in eliminating the misconceptions in pre-service science teachers. In the Turkish education system, students frequently encounter the subject of matter and its properties starting from the primary school 3rd grade according to the Science course teaching curriculum. When the relevant literature is examined, it shows that students have misconceptions about the particulate, space and motion nature of matter (Boz, 2006; Harrison \& Treagust, 1996; Kapıcı \& Akçay, 2016; Nakhleh \& Samarapungavan, 1999; Nakhleh, Samarapungavan \& Sağlam, 2005). According to Özmen \& Kenan (2007) and Balım \& Ormanc1 (2012), one of the main reasons for students' misconceptions about the particulate nature of matter is that the subject contains too many abstract concepts. Kapıcı and Akcay (2016) states that it may be another misconceptions for students to incorrectly associate the events encountered in daily events with the particulate structure of matter (Adadan, Irving \& Trundle, 2009) or to interpret their particulate structure model according to the physical state of matter (Özalp, 2011). The findings of this study showed that argumentation-supported PBL was effective in understanding the macroscopic and microscopic dimensions of the particulate, space and motion nature of matter and the relationships between these dimensions. In this respect, it was observed that students were able to use all the skills that are considered important in terms of understanding the relevant chemistry subject correctly and clearly in argumentation-supported PBL: such as interacting actively in learning environments, making claims and justifications, using experimental practices as supporters, making scientific explanations after observations, using rebuttal skills for the scientific explanations of other group mates. 


\section{REFERENCES}

Adadan, E., Irving, K. E., \& Trundle, K. C. (2009). Impacts of multi-representational instruction on high school students' conceptual understandings of the particulate nature of matter. International Journal of Science Education, 31(13), 1743-1775.

Abraham, M. R., Gryzybowski, E. B., Renner, J. W., \& Marek, A. E. (1992). Understanding and misunderstanding of eighth graders of five chemistry concepts found in textbooks. Journal of Research in Science Teaching, 29(2), 105-120.

Akman, S., \& Özdilek, Z. (2018). Evaluation of conceptual understanding of students on structure of matter with formative assessment question. Academy Journal of Educational Sciences, 2(2), 106-119.

Akpınar, E., \& Ergin, Ö. (2005). Student views on the problem-based learning approach. Inonu University Journal of the Faculty of Education, 6(9), 3-14.

Ali, R., Hukamdad, D., Akhter, A., \& Khan, A. (2010). Effect of using problem solving method in teaching mathematics on the achievement of mathematics students. Asian Social Science, 6(2), 67-72.

Alper, A., \& Deryakulu, D. (2008). The effect of cognitive flexibility on students' achievement and attitudes in web mediated problem based learning. Education and Science, 33(148), 49-63.

Andersson, B. (1986). Pupils' explanations of some aspects of chemical reactions. Science Education, 70(5), 549563.

Atasoy, B. (2018). Madde (pp.34-58), (Editor: Atasoy. B.) Genel kimya, Palme Publishing.

Ayas, A., \& Demirbaş, A. (1997). Turkish secondary students' conceptions of introductory chemistry concepts. Journal of Chemical Education, 74(5), 518-521.

Ayas, A., Yaman, F., \& Kala, N. (2010). Bilgisayar destekli tahmin-gözlem-açılama (TGA) etkinlikleriyle öğrencilerin günlük hayatta karşılaşılan asitler ve bazlar ve bunlar arasında gerçekleşen reaksiyonlar hakkındaki anlamalarının belirlenmesi. IX. National Science and Mathematics Education Congress. Dokuz Eylul University. Izmir.

Aydoğdu, Z. (2017). Investigation of effects the argumentation based science teaching on the academic success, motivation, interest and attitudes towards science. [Unpublished master's thesis]. Sakarya University Institute of Education Sciences, Sakarya.

Ayvacı, H. Ş., \& Durmuş, A. (2016). Effect of laboratory activities based on "predict-observe-explain (POE)" method on pre-service science teachers' academic achievement on "heat and temperature" subject. Pamukkale University Journal of Education, 39, 101-118.

Balaydın, H. T., \& Altınok, O. (2018). POE strategy in science education in Turkey: A Meta-Synthesis. Recep Tayyip Erdogan University Journal of Social Sciences, 4(8), 427-444.

Balc1, C. (2015). The effect of scientific argumentation based learnings in teaching of "Cell division and inheritance" units to 8th grade students. [Unpublished master's thesis]. Adnan Menderes University, Institute of Science, Aydin.

Balım, A. G., \& Ormancı, Ü. (2012). Determining the level of primary school students' understanding of the chapter "structure of matter" through drawings and analysing of different variables. Journal of Research in Education and Teaching, 1(4), 28. 
Banta, T. W., Black, K. E., \& Kline, K. A. (2000). PBL 2000 plenary address offers evidence for and against problem based learning, PBL Insight to solve, to learn, together. A newsletter for undergraduate Problem Based Learning from Stamford, 3(3).

Bar, V., \& Travis, A. S. (1991). Children's views concerning phase changes. Journal of Research in Science Teaching, 28(4), 363-382.

Belland, B. R., Glazewski, K. D., \& Richardson, J. C. (2011). Problem-based learning and argumentation: Testing a scaffolding framework to support middle school students' creation of evidence-based arguments. Instructional Science, 39(5), 667-694.

Birinci Konur, K., \& Ayas, A. (2010). Pre-service primary teachers' understanding level of the relationship between Heat-Volume-Pressure in gases. Journal of Turkish Science Education, 7(3), 128-142.

Birgegard, G., \& Lindquist, U. (1998). Change in student attitudes to medical school after the introduction of problem based learning. Medical Education, 32, 46-49.

Boz, Y. (2006). Turkish pupils' conceptions of the particulate nature of matter. Journal of Science Education and Technology, 15(2), 203-213.

Cassel, D. G. (2002). Synergistic argumentation in a problem-centred learning environment. Doctoral dissertation, The University of Oklahoma, Oklahoma.

Cerezo, N. (2004). Problem based learning in the middle school: A research case study of the perceptions of atrisk females. Research in Middle Level Education, 27(1), 1-13.

Coştu, B., Ayas, A., Açıkkar, E., \& Çalık, M. (2007). At which level are concepts about Solubility topic understood? Boğazici University Journal of Education, 24(2), 13-28.

Creswell, J. W. (2012). Educational research: Planning, conducting, and evaluating quantitative and qualitative research (4thed.). Boston, MA: Pearson.

Çakmakcı, G., Leach, J., \& Donnelly, J. (2006). Students' ideas about reaction rate and its relationship with concentration or pressure. International Journal of Science Education, 28(15), 1795-1815.

Çalık, M. (2003). A Cross-age study of level of students' understanding related to concepts in solution chemistry. [Unpublished master's thesis]. Karadeniz Technical University, Institute of Science, Trabzon.

Çalık, M., \& Ayas, A. (2008). A critical review of the development of the Turkish science curriculum. In R. K. Coll \& N. Taylor (Eds.), Education in context: An international examination of the influence of context on science curricular development and implementation (pp. 161-174). Rotterdam: Sense.

Çalık, M., \& Ayas, A. (2005). A comparison of level of understanding of eighth grade students and science student teachers related to selected chemistry concepts. Journal of Research in Science Teaching, 42(6), 638667.

Çavdar, O., Okumuş, S., \& Doymuş, K. (2016). Determining understandings related to the particulate nature of matter of students at science education. Mustafa Kemal University Journal of Social Sciences Institute, 13(33), 69-93.

Çekbaş, Y. (2017). The evaluation of the effect of an astronomy course based on argumentation on pre-service science teachers' nature of science, pseudo-science and epistemological beliefs. [Unpublished doctoral dissertation]. Pamukkale University Institute of Educational Sciences, Denizli. 
Demircioğlu, G., Özmen, H., \& Ayas, A. (2001). Kimya öğretmen adaylarının asitler ve bazlar ile ilgili yanlış anlamalarmm belirlenmesi. Science Education Symposium in Turkey at the Beginning of the New Millennium, T.C. Maltepe University, 7-8 Eylül.

Demircioğlu, H., \& Vural, S. (2014). The effect of constructivist approach on the gifted students' understanding: “Melting - freezing". Dicle University Journal of Ziya Gökalp Faculty of Education, 22, 31-50.

Demirel, R. (2015). The effect of individual and group argumentation on student academic achievement in force and movement issues. Journal of Theory and Practice in Education, 11(3), 916-948.

Demirel, T. (2017). The effect of augmented reality activities supported by argumentation approach on academic achievement, critical thinking skills, motivation towards science and technology course and argumentation skills. [Unpublished doctoral dissertation]. Çukurova University Institute of Social Sciences, Adana.

Dochy, F., Segers, M., Van den Bossche, P., \& Gijbels, D. (2003). Effects of problem-based Learning: A metaanalysis. Learning and Instruction, 13(5), 533-568.

Driver, R., Newton, P., \& Osborne, J. (2000). Establishing the norms of scientific argumentation in classrooms. Science Education, 84, 287-312.

Duch, B. J., Groh, S. E., \& Allen, D. E. (2001). Why problem-based learning? A case study of institutional change in undergraduate education. The power of problem-based learning, Eds: Duch, B. J., Groh, S. E. and Allen, D. E., Sterling, Virginia, 3-11.

Ebenezer, J. V., \& Fraser, D. M. (2001). First year chemical engineering students' conceptions of energy in solution processes: Phenomenographic categories for common knowledge construction. Science Education, 85(5), 509-535.

Erduran, S., \& Jiménez-Aleixandre, M. P. (2008). Argumentation in science education. Perspectives from classroom-based research. Dordrecht: Springer.

Eyceyurt Türk, G. (2017) The effect of argumentation-supported problem based learning applications on the acid / bases and gases success of pre-service science teachers. [Unpublished doctoral dissertation]. Gazi University Institute of Educational Sciences, Ankara.

Fensham, P. J., Gunstone, R. F., \& White, R. T. (1995). Science content and constructivist views of learning and teaching. In P. J. Fensham, R. F. Gunstone \& R. T. White (Eds.), The content of science (pp. 1-8). London: The Falmer Press.

Garnett, P. J., \& Treagust, D. F. (1992). Conceptual difficulties experienced by senior high school students of electrochemistry: Electric circuits and oxidation-reduction equations. Journal of Research in Science Teaching, 29(2), 121-142.

Gonzalez, F. M. (1997). Diagnosis of Spanish primary school students' common alternative science concepts. School Science and Mathematics, 97(2), 68-74.

Griffiths, A. K., \& Preston, K. R. (1992). Grade-12 students' misconceptions relating to fundamental characteristics of atoms and molecules. Journal of Research in Science Teaching, 29(6), 611-628.

Hackling, M. W., \& Garnett, P. J. (1985). Misconception of chemical equilibrium. European Journal of Chemical Education, 7(2), 205-214.

Hazel, E., \& Prosser, M. (1994). First year university students' understanding of photosynthesis: Their study strategies and learning context. The American Biology Teacher, 56, 274-27. 
Harrison, A. G., \& Treagust, D. F. (1996). Secondary students' mental models of atoms and molecules: implications for teaching chemistry. Science Education, 80(5), 509-534.

Hewson, M. G., \& Hewson, P. W. (1983). Effect of instruction using students' prior knowledge and conceptual change strategies on science learning. Journal of Research in Science Teaching, 20(8), 731-743.

Kalemkuş, J. (2018). Investigation the effects of science teaching based on experiments and argumentation-based science teaching on some variables. [Unpublished master's thesis]. Necmettin Erbakan University, Institute of Educational Sciences, Konya.

Kalın, B., \& Arıkıl, G. (2010). Misconceptions possessed by undergraduate students about the topic "Solutions". Necatibey Faculty of Education Electronic Journal of Science and Mathematics Education, 4(2), 177206.

Kapıcı, H. Ö., \& Akçay, H. (2016). Particulate nature of matter misconceptions held by middle and high school students in Turkey. European Journal of Education Studies, 2(8), 43-58.

Karakaş, H. (2018). Effect of argumentation-based teaching carried out for environment-energy subjects on critical thinking, academic achievement and argumentation skills of classroom teacher candidates. [Unpublished doctoral dissertation]. Gazi University Institute of Educational Sciences, Ankara.

Karamustafaoğlu, S. (2018), 21.yüzyıl becerileri ve fen öğretimi, Karamustafaoğlu, O., Tezel, Ö. \& Sarı, U., (Edt.), Güncel yaklaşım ve yöntemlerle etkinlik destekli fen öğretimi, Pegem Akademi.

Karslı, F., \& Çalık, M. (2012). Can freshman science student teachers' alternative conceptions of "electrochemical cells" are fully diminished? Asian Journal of Chemistry, 23(12), 485-491.

Kelly, O., \& Finlayson, O. (2009). A hurdle too high? Students' experience of a PBL laboratory module. Chemistry Education Research and Practice, 10(1), 42-52.

Kenan, O., \& Özmen, H. (2011). "Maddenin tanecikli yapısı" ünitesine yönelik geliştirilen zenginleştirilmiş bilgisayar destekli öğretim materyalinin tanıtımı. 5th International Computer \& Instructional Technologies Symposium, 22-24 September, Firat University, Elazığ.

Kılınç, A. (2007). Problem-based learning. Kastamonu Journal of Education, 15(2), 561-578.

Kolomuç, A., \& Tekin, S. (2011). Chemistry teachers' misconceptions concerning concept of chemical reaction rate. Eurasian Journal of Physics and Chemistry Education, 3(2), 84-101.

Kuhn, D. (2010). Teaching and learning science as argument. Science Education, 94(5), 810 - 824.

Liew, C. W., \& Treagust, D. F. (1998), The effectiveness of Predict-Observe-Explain tasks in diagnosing students' understanding of science and in identifying their levels of achievement, Paper presented at the Annual Meeting of The American Educational Research Association, San Diego.

Maskill, R., \& Cachapuz, A. F. C. (1989). Learning about the chemistry topic of equilibrium: The use of word association tests to detect developing conceptualizations. International Journal of Science Education, 11(1), 57- 69.

McGhee, M. (2015). The effects of argumentation scaffolding in a problem-based learning course on problem-solving outcomes and learner motivation. [Doctoral dissertation], The Florida State University.

Ministry of Education, (MoNE), (2018). Science course curriculum of primary education institutions (3, 4, 5, 6, 7 and 8th grades). Board of Education and Discipline, Ankara. 
Mısır, M. E., \& Laçin Şimşek, C. (2017). Yedinci sınıf öğrencilerinin maddenin tanecikli yapısı ile ilgili kavram yanılgılarına dijital öykülerin etkisi, VIII. International Graduate Education Symposıum, Proceedings Book, 46, Cyprus Social Sciences University.

Meşeci, B., Tekin, S., \& Karamustafaoğlu, S. (2013). Detection of misconceptions about the particulate nature of matter. Dicle University Social Sciences Institute Journal, (9), 20-40.

Nakhleh, M. B. (1992). Why some students don't learn chemistry: Chemical misconceptions. Journal of Chemical Education, 69(3), 191.

Nakhleh, M. B. \& Samarapungavan, A. (1999). Elementary school children's beliefs about matter. Journal of Research in science Teaching, 36(7), 777-805.

Nakhleh, M. B., Samarapungavan, A., \& Saglam, Y. (2005). Middle school students' beliefs about matter. Journal of Research in Science Teaching, 42(5), 581-612.

Namdar, B., \& Demir, A. (2016). A spider or an insect? Argumentation-based classification activity for fifth graders. The Journal of Inquiry Based Activities (JIBA), 6(1), 1-9.

Nussbaum, E. M., \& Edwards, O. V. (2011). Critical questions and argument stratagems: A framework for enhancing and analyzing students' reasoning practices. Journal of the Learning Sciences, 20(3), 443-488.

Osborne, R., \& Cosgrove, M. (1983). Children's conceptions of the changes of state of water. Journal of Research in Science Teaching, 20(9), 825-838.

Osborne, R. J., \& Gilbert, J. A. (1980). "A method for investigation of concept understanding in science", European Journal of Science Education, 20(9), 825-838.

Osborne, J., Erduran, S., \& Simon, S. (2004). Enhancing the quality of argumentation in school science. Journal of Research in Science Teaching, 4(10), 994-1020.

Özalp, D. (2011). Development of two-tier diagnostic items based on ontology in the topic of the particulate nature of matter. Journal of National Education, 41(191), 135-156.

Özdemir, O. (2015). Pre-service teacher's arguments about hereditary similarities and variations. Pamukkale University Journal of Education, 38(38), 143-155.

Özeken, Ö. F., \& Yıldırım, A. (2011). The effect of problem-based learning method in teaching acid-base subject on science teachers' academic success. Pegem Journal of Education and Instruction, 1(1), 33-38.

Özmen, H. (2004). Kimya öğretmen adaylarının asit ve baz kavramlarılla ilgili bilgilerini günlük olaylarla ilişkilendirebilme düzeyleri. Gazi University Kastamonu Education Journal, 11(2), 317-324.

Özmen, H. (2005). Misconceptions in chemistry teaching: A literature survey. The Journal of Turkish Educational Sciences, 3(1), 23-45.

Özmen, H., \& Demircioğlu, G. (2003). The effect of concept change texts in eliminating student misconceptions about acids and bases. Journal of National Education, 159, 111-119.

Özmen, H. \& Kenan, O. (2007). Determination of the Turkish primary students' views about the particulate nature of matter. Asia-Pacific Forum on Science Learning and Teaching, 8(1), 1-15.

Pardo, J. Q., \& Partoles, J. J. S. (1995), Students and teachers misapplication of Le-chatelier's principle: Implications for the teaching of chemical equilibrium. Journal of Research in Science Teaching, 32(9), 939957.

Sagor, R. (2000). Guiding school improvement with action research. Association for Supervision and Curriculum Development (ASCD) Press. 
Scaife, J., \& Abdullah, A. (1997). Using interviews to assess children's understanding of science concepts. School Science Review, 78(285), 79-84.

Smith, K. J., \& Metz, P. A. (1996). Evaluating student understanding of solution chemistry through microscopic representations. Journal of Chemical Education, 73(3), 233.

Şahin, E. (2016). The effect of argumentation based science learning approach (ABSL) on academic success, metacognition and critical thinking skills of gifted students. [Unpublished doctoral dissertation]. Gazi University Institute of Educational Sciences, Ankara.

Şengül, Ö. (2018). Science teachers' epistemological beliefs, PCK of argumentation, and implementation: An exploratory study. [Doctoral dissertation]. Georgia State University.

Şenocak, E., \& Taşkesenligil, Y. (2005). Problem-based learning and its applicability in science education. Gazi University Kastamonu Journal of Education, 13(2), 359-366.

Taber, K. S. (1999). Ideas about ionization energy: A diagnostic instrument. School Science Review, 81(295), 97104.

Tatar, E., Oktay, M., \& Tüysüz, C. (2009). Advantages and disadvantages of problem based learning in chemistry education: A case study. Erzincan University Journal of Education Faculty, 11(1), 95-110.

Torp, L., \& Sage, S. (2002). Problems as possibilities: Problem-based learning for K-16 education (2nd ed.). Alexandria, VA: Association for Supervision and Curriculum Development.

Tosun C., Tatar, E., Şenocak, E., \& Sözbilir, M. (2015) Kimya öğretiminde probleme dayalı öğretim uygulamaları. A. Ayas \& M. Sözbilir (Ed.), In Kimya Öğretimi (s.171-194). Ankara. Pegem Publishing.

Treagust, D. F., \& Chandrasegaran, A. L. (2007). The Taiwan national science concept learning study in an international perspective. Journal of Science Education, 29(4), 391-403.

Tüysüz, C. (2009). Development of two-tier diagnostic instrument and assess students' understanding in chemistry. Scientific Research and Essay, 4(6), 626-631.

Voska, K. W., \& Heikkinen, H. W. (2000). Identification and analysis of student conception used to solve chemical equilibrium problems, Journal of Research in Science Teaching, 37(2), 160-176.

White, R. T., \& Gunstone, R. F. (1992), Probing understanding, The Falmer Press, London.

Yamtinah, S., Indriyanti, N.Y., Saputro, S., Mulyani, S., Ulfa, M., Mahardiani, L., Satriana, T., \& Shidiq, A.S. (2019). The identification and analysis of students' misconception in chemical equilibrium using computerized two-tier multiple-choice instrument, Journal of Physics: Conference Series, 1157(4).

Yıldırım, A., Demircioğlu, G., Özmen, H., \& Ayas, A. (2000). Kimyasal denge konusunun öğrenciler tarafından anlaşılma düzeyi ve karşılaşılan yanılgılar. IV. Science Education Congress Proceedings Book, 427-432.

Zoller, U. (1990), Students' misunderstandings and misconceptions in college freshman chemistry (general and organic). Journal of Research in Science Teaching, 27(10), 1053-1065. 